University of Rhode Island

DigitalCommons@URI

Open Access Master's Theses

1961

\title{
A Study of the Use and Non-Use of Anecdotal Records in Elementary Schools
}

Sylvia Antonelli

University of Rhode Island

Follow this and additional works at: https://digitalcommons.uri.edu/theses

\section{Recommended Citation}

Antonelli, Sylvia, "A Study of the Use and Non-Use of Anecdotal Records in Elementary Schools" (1961). Open Access Master's Theses. Paper 1362.

https://digitalcommons.uri.edu/theses/1362

This Thesis is brought to you for free and open access by DigitalCommons@URI. It has been accepted for inclusion in Open Access Master's Theses by an authorized administrator of DigitalCommons@URI. For more information, please contact digitalcommons-group@uri.edu. 


\section{A STUDY OF THE USE AND NON-UST OF}

ANECDOTAI RECORDS IN

EIFHAENTARY SCHOOLS

BY

SYIVIA ANTONEELI

A THESIS SUBMITTED IN PARTIAT FUIEIIIMENT OF THE REQUIREMENTS FOR THE DDERRFE OF

MLASTER OF SCIENCE

IN

EDUCATION

UNIVHRSITY OF RHODE ISIAND

1961 


\section{MASTER OF SCIENCT THESIS}

\section{OF}

SYLVIA ANTONDIII

Approved:

Major Professor

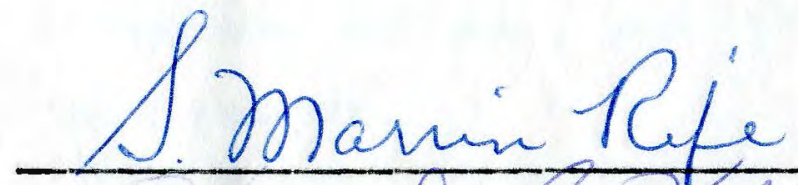

Head of Department

Dean of the College of Arts and Sciences

Dean of Graduate Studies

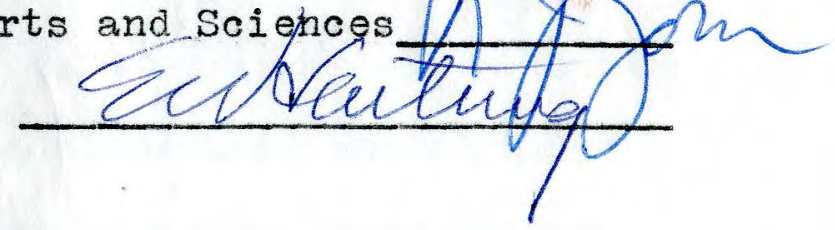

UNIVIERSITY OF RHODE ISIAND

1961 


\section{ACKNOTTEDGEMENTS}

The author wishes to acknowledge her indebtedness to her graduate advisor, Dr. S. Marvin Rife, for his assistance and guidance; to Dr. Thomas Nally for his suggestions and constructive criticisms; and to Dr. E. Kenneth Carpenter for his helpful suggestions. 


\section{ABSTRACT}

For many years there has been a question as to the extent to which anecdotal records can be used effectively to help the teacher better understand her students. This is one of the areas of education in which little up-todate study has been done. The problem involved in this thesis was to determine to what extent anecdotal records were being used in Warwick elementary schools, and in those schools in which they were not used, some of the possible reasons for their non-use.

From a study of the literature on anecdotal records, criteria for writing, using, and keeping anecdotal records were presented as they might apply to the furthering of guidance in the elementary schools. An introductory letter explaining anecdotal records was constructed to accompany the interview type questionnaire which was constructed around the criteria. Personal interviews were conducted with twenty elementary school principals, representing twenty-nine of the Warwick elementary schools, who distributed questionnaires to all teachers. From an analysis of this study of the use or non-use of anecdotal records in the Warwick elementary schools, results were pre- 
sented as they applied to the problew, providing the basis for conclusions and recommendations.

An evaluation of data from the interviews with the elementary school principals and questionnaires from teachers of Warwick revealed some conclusions pertinent to the study. The fact that in forty per cent of the interviews it seemed evident that the principals had some misconceptions concerning the true meaning of anecdotal records was of major significance. Although a few principals were strongly in favor of the use of anecdotal records and a few expressed a negative reaction, the majority of principals appeared only mildly enthusiastic.

A major phase of the study was the questionnaire administered to the teachers. Anecdotal records were most frequently used for parent conferences and for problem cases. Although physical well-being or lack of it can play an important part in a child's behavior, the questionnaire revealed that records were seldom kept for children exhibiting poox health only. The most frequently mentioned benefit experienced by teachers from the use of anecdotal records was better understanding of the pupil. Accuracy and previous teacher's experiences were also mentioned as positive benefits. The teachers listed time consumption as the greatest obstacle standing in the way of regular and sustained use of anecdotal 
records. Ifmited knowledge in psychology was also mentioned. The teachers seemed to feel that it was the administration's responsibility to provide help in overcoming these obstacles. Increased initiative and resourcefulness of the teachers themselves and more study were also suggested.

As a result of this investigation, the following recomendations were made. The writing, keeping, and using of anecdotal records should be voluntary. Inservice training courses and workshops would make the teacher more aware of the value of anecdotal records. Case conference techniques in which the teacher and guidance consultant discuss a youngster should be established. The records should be applied and used to help the child. Extra clerical help should be made available to assist the teacher. Anecdotal records should be kept for all children. Year-end summaries should be prepared by the guidance consultant, following a conference with each teacher. 
TABIE OF CONTENTS

Page

ACKNOWLEDGEMIHNTS . . . . . . . . . . . . ii

ABSTRACT .................... ili

IIST OF TABITES ............... . vii

Chapter

I. STATPEMENT OF THE PROBIEMA . . . . . . . I

II. BACKGROUND FOR THE STUDY . . . . . . 7

III. METHODS OF INVESTIGATION . . . . . . 26

IV. PRESENTATION OF DATA . . . . . . . . 34

V. SUMMLARY AND RECOMMTHDATIONS . . . . 50

Summary

Recommendations

BIBLIOGRAPHY . . . . . . . . . . 61 


\section{IIST OF TABLES}

Table

Page

1. Schools, Grades, and Children Represented in the Questionnaire Responses...... 37

2. Analysis of Frequency of Use of Anecdotal Records by Fifty-Nine Teachers Using Them . 38

3. Frequency of Mention by Elementary Teachers of Conditions which Prompted the Use of Anecdotal Records ............

4. Positive Benefits sxperienced by Elementary Teachers from the Use of Anecdotal Records.

5. Obstacles Accounting for the Irregular and Unsustained Use of Anecdotal Records by Elementary Teachers ..........

6. Flementary Teachers' Suggestions for Overcoming Obstacles to the Use of Anecdotal Records

7. Estimate of Practicality, Value and Usefulness of Anecdotal Records by 106 Hilementary Teachers ............... 


\section{CHAPTER I}

\section{STATEMAHNT OF THE PROBIEM}

The purpose of this study was to investigate to what extent anecdotal records were being used by elementary school personnel in the Warwick system. Where they were not used, an attempt was made to determine some of the possible reasons for their non-use. During the last twenty-five years, anecdotal records have come to be considered an important part of the cumulative record. For many years there has been a question as to the extent to which anecdotal records can be used effectively in aiding the teacher to better understand her students. Although educational literature has supported the use of anecdotal records, it is the writer's hypothesis that for various reasons anecdotal records are not being used as extensirely as they should be; and, that the reasons for their non-use are those which could be overcome with a guidance-oriented staff.

For this investigation Zahn's definition of an anecdotal record as "a simple objective statement of an incident deemed by the observer to be significant with 
respect to a given pupil" ${ }^{1}$ was used.

These records generally fall into three types. The first type which originated in the early 1930 's at the Rochester Athenaeum and Mechanics Institute (now the Rochester Institute of Technology) may be characterized by a simple statement.

The anecdote is a record of some significant item of conduct, a record of an episode in the life of a student; $a$ word picture of the student in action; the teacher's best effort at taking a word snapshot at the moment of the incident; any narrative of events in which the student takes such a part as to reveal something which may be significant about his personality.

The second type of anecdote is a record of observation with an interpretation. Since the interpretation involves the teacher's opinion or what she thinks happened, and is not restricted entirely to what actually happened, it is subjective rather than objective. Therefore, it is separated from the anecdote, with the interpretation so labeled. In the interpretation the teacher may interject her opinion.

I Willard D. Zahn, "The Anecdotal Record in Relation to Child Development, "Education for Dynamic Citizenship, Twenty-Fourth Yearbook, Schoolman's Week Proceedings, (Pennsy Irania University School of Education, March, 1937). pp. 294-300.

2J. A. Randall, "The Anecdotal Behavior Journal," Progressive Education, XIII (January, 1936), p. 22. 
The third type of anecdote is accompanied by a secommendation. As the teacher develops the behavior record through the year, her knowledge of the child's personality pattern, abilities, likes, and dislikes increases. Hence, her recomendation makes the record more complete and valuable. The recommendation, like the interpretation, is not part of the behavior record and should be separated from it. This recommendation may be directed to the student, the home visitor, the school nurse, the parent, or some supervising officer.

The anecdotal record is an instrument generally considered to be ideally suited to the elementary school. The use of the anecdotal record serves at least five important purposes.

First, through continuous use throughout the elementary grades, it helps each teacher to have the benefit of the previous teachers' experiences in better understanding of each child. She may see a child in one aspect only. It can be used to measure consistently a pupil's development over a long period of time.

Second, it helps each teacher to become aware of the problems of individual children. Because the anecdotal record is written freely in sundry types of social situations where behaviors are observed, it is less carefully controlled than other devices such as time-sampling technique, which is concerned mainly with research directed toward the study of groups and development of 
pinciples. The anecdote directs the attention of the teacher away from subject matter and toward the individual pupil. It provides a variety of descriptions about the uninhibited behavior of pupils in diverse situations, thus contributing to an understanding of the basic personality pattern of each individual and of changes in pattern. Third, it provides data for guidance, especially for parent-teacher conferences and for aiding clinical service. The anecdotal record helps keep in the teacher's mind a complete picture of individual growth. It gives specific and exact descriptions of personality instead of rague generalizations. The unique contributions of the anecdotal record to the case history of the student is that it is a dynamic description of a speoific episode and the situation in which it took place.

Fourth, it facilitates identification or diagnosis of children who may need remedial work. The anecdotal record is meant to be a practical study device for improving professional insights about such disabilities as speech handicaps, reading deficiencies, and defects in study habits and attitudes.

Fifth, it enables the school administration to have a better basis for making improvements in the curriculum. For example, evaluation of anecdotal records may indicate where there should be general presentation of material in character development to satisfy the needs of the school cormunity . 
The records generally in use tend to emphasize achievement in subject matter and give relatively little Information about such items of behavior as are necessary for counseling with students in matters pertaining to character or personality development. If the personality pattern is to mature in such ways as to enhance social rather than self-centered attitudes, counseling must be based on reliable observations of the activity patterns of the individual student, recorded during the successive phases of his maturation.

Anecdotal records should not be considered in isolation, but cumulatively. The use of anecdotal records in elementary schools is critical. At the outset, it is essential to give all teachers in the school an understanding of what is involved and to create a willingness to cooperate in trying out the method. It is the teacher whose attitude and cooperation are most essential to the success of the plan, because as constant observers of pupil behavior, they are in a better position to know the children. Since teachers must be depended upon to write the majority of anecdotes, the anecdotal record plan will fail unless teachers believe in it. When teachers see an actual and immediate need for anecdotal records in carrying on their work, it is more likely that they will be ready to accept them.

A great deal is being said about encouraging able students to make the best use of their potentials. This 
should be done in the elementary school where one can get clues on individual positive or negative development. If negative development is spotted at this stage, it is easier to correct it than if it is allowed to develop over a long period of time. In the same way that early detection of disease is desirable, early detection of negative factors is essential for positive development of personality. Since the anecdotal record is part of the ongoing record, reliable only if recorded continuously, a wise teacher selects positive as well as negative behavior for the record so that she can gain a complete picture.

Before determining techniques of appraial, one needs to know exactly what is being measured in terms of learning goals set up by the school. Anecdotes may be recorded as positive (in accordance with goal) or negative (opposed to goal). In that way, a teacher can get a picture of the growth and development of the entire class.

For the purpose of this study, the Warwick elementary school was used as the laboratory for an investigation of the use and possible reasons for the non-use of anecdotal records. The cooperation of the superintendent was secured and permission was obtained to visit and interview the principal of each school and through her to obtain responses from elementary teachers in every school in the system. 


\section{BACKGROUND FOR THE STUDY}

The literature on anecdotal records during the past thirty years, although tending to approach the problem from many angles, still represented for the most part peculative discussion. With the exception of the Rochester Athenaeum and Mechanics Institute, the investigations have been of a general exploratory type to determine whether or not teachers could collect anecdotes. The studies have either been interspersed with teachertraining periods or restricted to very limited situations. For example, student teachers have been utilized to collect records for a few children or for over short periods of time. In general, emphasis has been upon the mechanics of the problem of how many anecdotes teachers could collect, whether or not they were favorable, and into which categories they fell. Some attempts have been made to use the anecdotes for special purposes, such as determining misdemeanors of children, measuring character development, and training teachers. Up to the present, the anecdotal method has not as yet been in common use in the classroom. 
The nature of anecdotal records suggests limitations and dangers in the preparation and use of anecdotal rocords. This fact helps explain one of the reasons for their limited use. It is difficult to accurately observe and correctly record an incident. Court records provide evidence that observation reports are often inaccurate. This is especially true in a school situation in which the teacher's attention is divided between behavior incidents and keoping the discussion moving. It takes a superior person to do more than one thing at the same time and do it weIl.

It is difficult to write anecdotal records with complete objectivity, but practice will help overcome this liability. A report of the incident should be as accurate and imartial as an $x$-ray photograph. The fact that observations tend to be biased unless gathered with reference to specific objectives has been indicated in a study made by Thomas in which she worked with observers who had no definite direction given their observations and found that:

the ordinary observational technique was shown to be totally invalid as an instrument for recording behavior for research purposes. A check-up was made by having several observers make diary records of the social behavior of given children. There was a marked tendency for a given recorder to note one aspect in the record; another in the next record. Although trained to make objective records in the sense of including overt reactions only, the result was necessarily subjective in that the record, usually unconsciously, selected specific parts of the total behavior act. This selection became, 
furthermore, invariably inconsistent over a period of time. The obvious solution to this difficulty was to break up the behavior-complex into relatively simple units which would enable a record to be made of every occurrence of these behavior units.

Since the central purpose of every anecdotal record is to help the entire school staff to obtain better understanding of a student, such records should never be written to explain or justify action on the part of the teacher.

A beharior incident is not set apart from the setting in which it occurred or reported in isolation. Under the stimulus of group sentiment and action a pupil may behave in a way that is not typical of him. A brief description of the background against which an action occurred is often essential in reporting.

Since only a small proportion of the total number of significant behavior incidents for any pupil will enter the anecdotal records, it is important to have enough anecdotal material accumulated from which to select, because a small number will not give valid evidence of the total pleture. It is neceasary that they be selected with a ereat deal of care by an expert. In a study by Goodenough it was found that the reliability of observations can be greatly increased by

${ }^{1}$ Dorothy Swaine Thomas and Associates, New Techmiques for Studying Social Behavior, Child De velopment Tonographs No. I, Bureau of Publications, Teachers College, Columbia University, I939. 
increasing the number of observational samples. Sixteen graduate students with no experience in observational techniques each observed a single type of activity. An average of ten observations per child was secured by each student. Reliability was found highest for "dramatic play," and for "general activity," while low correlations were found for "physical activity," "laughter," "social participation," "self-help," and "responses to food." However, the observations were found to be too few and too brief to be of much value. ${ }^{1}$ Morpheus Smith made a study concerning the relationship between the number of anecdotes recorded and the validity of the records. He found that the greater the number of observations, the more valuable the interpretations that can be made from them. 2

Anecdotal records cannot be handled carelessly by irresponsible people because there is danger that unfortunate behavior incidents on the part of some pupils may hinder their success long after the behavior is typical of them. The individual anecdote, if entrusted

IPlorence I. Goodenough, Measuring Traits by Means of Repeated Short Samples," Journal of Juvenile Research, XII, 1928, pp. 230-235.

2Horpheus Smith, "Concerning the Magnitude of the Behavior Sample for the Study of Behavior Traits in Children," Journal of Applied Psychology, XV (October, 1931), pp. $480-485$. 
to a person who is personally and professionally responsible, will not be misused.

Adopting the anecdotal record system is a huge undertaking. It will add to the load of the entire school, especially counselors and clerical staff. A definite and workable plan is developed before undertaking writing anecdotes. Among those opposed to the anecdotal method is Darsie.

To expect a classroom teacher, even a gifted and devoted teacher, to evaluate not only growth in social concern but in a whole group of equally complex intangibles, and at the same time to plan and carry out a program of inspired teaching is impossible and absurd. Something in the nature of a virile proletarian revolt demanding an end to nebulous thinking and a clear-cut analysis of objectives and procedures would clear the air immensely. It is the most urgent single need in education today. It might even make evaluation of intangibles quite unnecessary. 1

Although some do not feel that anecdotal records are too time consuming, they have indicated that there are problems in the field of anecdotal recording which need answers.

Although numerous values are claimed for the anecdotal technique, there still remain many unsolved and difficult problems of the reliability and validity of anecdotes. Whether or not the difficulties involved in such a statistical analysis can be surmounted remains an open question because of the innumerable variables with which the researcher is confronted.

IH. I. Darsie, "Fvaluating the Intangibles," Galifornia Journal of Secondary Education, XII (March, 3939), pp. 275-277. 
Anecdotes are basically individual from the point of view of the observer and the person being observed. 1

Sampling is a problem needing solution. For example, how long a time should one use, how many samples should be gathered, how reliable are such data, and what should one record? Other problems are the validity and pertinency of data. ${ }^{2}$

Indications in the anecdotal record should be studied and an attempt made to improve the adjustment of the pupils when the anecdotes show that better adjustment is needed. However, adjustment is usually a long term process. There is some danger that anecdotal records will throw the need for the better adjustment of certain pupils into such high relief that too marked an effort will be made to speed up the adjustment process. As indicated by Traxler, it is necessary that counselors remember that personality adaptions frequently involve the formation of new sets of habits and that time is required for this. 3

Undesirable behavior is likely to make a stronger

${ }^{1}$ L.I. Jarvie and llark Ellingson, A Handbook of the Anecdotal Behavior Journal, University of Chicago, 1930.

2 Fern H. Bowes, "The Anecdotal Behavior Record in Heasuring Progress in Character," Flementary School Journal, XXXIX (February, 1939), pp. 431-435. p. 131 .

3 Arthur E. Traxler, Techniques of Guidance, 1957 , 
impression on teachers than desirable behavior. There is some danger that the total effect of anecdotal records will be negative rather than positive. Harris found that verenty-six per cent of all items reported by teachers in a correctional school for boys were considered unfaroxable. ${ }^{1}$ This fact may be due to the type of school in which the study was made. Mocormick found about as many favorable as unfavorable anecdotes in the records that he studied. ${ }^{2}$

Jarvie found that as teachers collect information on pupils the anecdotes tend to become generalized statements rather than factual remarks. Anothor aspect of timing is a tendency to collect a disproportionate number of anecdotes in the beginning. Jarvie found that anecdotes were collected frequently during the early periods of residence of a pupil and that as many anecdotes had been collected on pupils who dropped out of school as on those who remained. ${ }^{3}$. Jarvie recommends that teachers guard against collecting a disproportionate

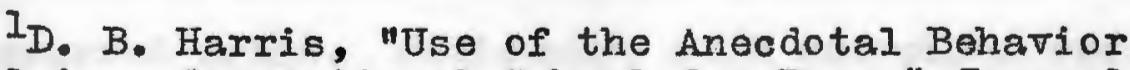
Journal in a Correctional School for Boys," Joumal of Juvenile Research, XXII (JuIy, 1938), pp. 162-168.

${ }^{2}$ C. F. McCormick, "Anecdotal Record in the Appraisal of Personality," School and Society, IIII (January 25, 1941), pp. 126-127.

3. I. Jarvie, "Some Factors Bearing on the Use of Anecdotal Records," American Educational Research Association: Official Report, 1940 . 
number of anecdotes in the beginning of the year. Many teachers tend to concentrate upon collecting several anecdotes in the beginning of the school year in an attempt to get to know and understand their pupils, in which process anecdotes can prove helpful. It may also be an attempt to be sure that there are enough anecdotes and they will not have to search for them later.

Traxler found that occasionally teachers will observe incidents that are not typical of the behavior of the pupil concerned. 1 For example, a first year teacher observed a youngster in the lunchroom. He had been known to the faculty to be a well-adjusted child who seemed to have little need for extra attention or who employed few attention getting devices. He looked at the teacher several times, and when he was sure that she was looking at him, he walked up to the wastebasket and threw his lunch into it. Immediately, other youngsters told the teacher of their classmate's action. The child smiled and looked pleased that he was the center of so much attention. The teacher made an anecdotal record of the incident. It never occurred again. Obviously, such untypical recording is of little value to the future user of the records.

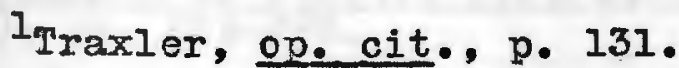


Anecdotal records have been put to mary uses. Blatz and Blott concerned themselves with the misdemeanors of children and found the results "satisfactory."I They believe that:

A research outlook upon the process of maladjustment in children requires that attention be paid to cases presenting all degrees of trouble from those who offer no concern to those who show the earliest signs of difficulty, as well as the more dramatic "problem" cases. This objective in case material necessitates contact with children under a variety of circumstances. The investigator's horizon should not be limited to the pathology of behavior; and he must relinquish preconceived ideas concerning what is normal and what not, trying rather first to record the salient facts and trends of behavior under known environmental conditions and with due allowance for the psychological make-up of the individuals concermed. ${ }^{2}$

In the fall of 1924 a public school in Toronto was selected as the laboratory for the study cited above. In order that the judgment of the teachers should all be alike it was outlined that a "misdemeanor" should signify "any act on the part of the child which necessitated the interruption of the teaching routine for the purpose of dealing with the pupil or pupils in question." A list of misdemeanors was compiled and used by the teachers.

I William E. Blatz and E. A. Blott, "Studies in Mental Hygiene of Children. Behavior of Public School Children: A Description of Method," Pedagogical Seminar and Journal of Genetic Psychology, XXXIV (December, 1927), pp. 552-582. 
Then misdemeanors could be referred to by numbers and lotters, thus saving time. This plan, although imperfect, has many advantages. It provides means for the objective recording of behavior and if not sufficiently objective can be made more so; it safeguards injecting the prejudices of the research staff into the situation, and likewise preconceptions of the teacher may be checked and evaluated by comparing the behavior types of the children in her class with the subsequent record. It informs one in a fairly comprehensive way on the main facts in the adjustment process of children in school attendance and thereby prepares the way for more intensive studies under adequately known conditions. ${ }^{1}$ However, in this study particular attention was given to negative rather than positive behavior.

A further function of anecdotal records is that of serving as an aid in clinical service. When pupils are referred to clinical workers for special study of their problems, there is great advantage in having aneodotal records available for these highly trained workers to interpret. Charters supported this view with a case cited at the Rochester Athenaeum and Mechanics Institute in which anecdotal records on a student were found to

$$
I_{\text {Ibid., pp. 557-581. }}
$$


contain as much information about a student as the psychiatrist had been able to derive from his observations. 1

Bright and Hunsucker found that another use of anecdotal records is teacher training in observation of pupils. 2 In a weekly seminar for all practice teachers an oral report is required in which the trainee traces the development of her class. In this report specific illustrations of the week's activities are cited. The director and other trainees listen and offer constructive criticisms, and trainees who use anecdotal records find the records helpful for this purpose. Training in the use of anecdotal records helped the trainee develop more precise techniques of observation so essential to every teacher's success.

Anecdotal records can be used with pupils to aid in their own self-appraisal. While in some cases, the anecdotes should not be shown to the pupils, each papil can profitably study the indications in many of the anecdotes about him in order to decide what he needs to do to improve. Jones and Galbraith cite the instance of an

IW. W. Charters, "A Character Development Study," The Personnel Journal, XII (August, 1933), pp. 119-123.

2Harold Bright and Florise Hunsucker, "Use of the Anecdotal Behavior Journal in Student Training," Teachers College Journal, Indiana State Teachors College, IX (September 16, ig 37), pp. 6-7. 
English teacher who, after a small amount of editing the anecdotes, showed them to a ninth grade boy who was underachieving and displaying a lack of interest in reading. As a result, the boy began to slowly develop an interest in reading and gradually assumed responsibiljty for independent reading and participation in class activities. ${ }^{1}$

Anecdotal records relieve individual teachers of the responsibility of making trait ratings and provide a basis for composite ratings. Trait ratings do not give a continuous picture, but anecdotal records can be continuous. The anecdote was adopted at the Athenaeum as an administrative substitute for improving the rating scale. At first it was proposed as a "trait action" upon which to base ratings. However, the Athenaeum was interested in helping each student acquire a functioning personality pattern. Since this pattern was unique for each student, the Athenaeum was not concerned with efforts to help set up a single standard pattern to which all students would strive to conform. It was the standard practice for each faculty nember to supply a minimum of one anecdote per week for each student registered in his class, as well as to supply anecdotes upon

$I_{\text {Arthur T. Jersild and Margaret F. Meigs, "Direct }}$ Observation as a Research Hethod," Review of Educational Research, IX (December, 1939), pp. 472-482, 597-599. 
activities observed outside the classroom. It was difficult for teachers to measure up to this expectation, since in large classes there was no observation of significant behavior for five or six weeks.

In an experiment conducted by Hamalainen in 1940, four basic findings were significant. First, by directing the teachers' attention to the many objectives of pupil Browth and encouraging them to record significant phases of that growth, teachers may overcome their predilection to consider pupils who are not always the best behaved as the least competent. ${ }^{I}$ An eight year old boy who had received poor grades had been considered by most teachers and his family to be a "problem case." He had a high I. Q. and was very verbal, talking extensively on many subjects which are advanced for most children of his age. He read above grade level and most of $\mathrm{hls}$ library books were on the fifth grade level. As leader and helper for the science fair, he performed, explained, and answered questions about all the science experiments with no help. He was extremely active and poorly behaved. However, from recording anecdotes on specific phases of his growth, the present teacher found that although he was not the best behared, he was not the least competent.

$I_{\text {Arthur I. Hamalainen, "An Appraisal of Anecdotal }}$ Records," Teachers College Contributions to Education, Columbia University, No. 891; 1943, p. 77. 
Second, it was found necessary that the anecdotal record method be regarded as separate from observational methods used by research workers. Even the well-prepared and interested teacher cannot obtain the disinterestedness and objectivity of the research worker whose sole function is often observation for certain specific action. It is probable that freeing the teacher for certain periods of time to be spent solely in observation might tend to increase this objectivity. Lacking such facilities, mach in-service training in methods of observation is probably necessary. ${ }^{l}$

Third, it was concluded that the background of the teacher will often indicate the type of anecdote recorded. The most significant anocdotes are those gathered by teachers who have had much work in psychology, mental hygiene, and child development. The teacher who does not understand what behavior is important at the age level at which she is working will record many meaningless anecdotes and make irrelevant diagnoses. ${ }^{2}$

Fourth, this finding concerned itself with the relationship of anecdotes to summaries made by individual teachers. Fnd of the year summaries based on anecdotes must necessarily reflect subjective biases of the teacher.

I Ibid., p. 82 .

2IbId., Chapter III, esp. p. 29. 
Because the factor of selection enters into the recording of anecdotes, much of the material of the summaries must necessarily reflect a "general impression." This suggeats that even sumaries based upon the anecdotes that have been recorded are often subjective. Wile the anecdotes, as the teacher re-reads them, offer concrete information for the summary, the complete summary can probably never be entirely based on anecdotal material. This is particularly true with respect to the reticent child. Therefore, it might be desirable to have the same person, the teacher, write the anecdotes and the summaries. 1

In 1939 an agency of the Commission on Teacher Education, the Division on Child Development and Teacher Personnel, established by the American Council on Education began a five-year program. This two-fold program consisted of a "collaboration center" for gathering and synthesizing the findings of recent research, and a fleld program providing consultant service to the cooperating collegiate institution and public school systems.

Prescott compared the results obtained in two different systems using different methods. The teachers in one school system attended lectures on scientific facts and explanatory principles about human growth, learning, behavior and adjustment. They engaged in research in

I Ibid., Chapter V. 
scientific materials and concepts as well as systematic study programs by teachers themselves, based on carefully selected bibliographies and led by collaborators who had "been through the mill." Although the scientific materials were more or less interesting to the teachers, these procedures fell far short of the program's anticipations. Despite earnest efforts the teachers were able to achieve only a very limited increase in understanding the motivation, behavior, needs, and adjustment problems of their own individual pupils or of the dynamies underlying group action in their own classrooms. ${ }^{1}$

However, in another school system, each participating teacher selected an individual child and studied him and his behavior intensively over a period of one or two years, reporting their findings periodically to each other in on-going child-study groups. Since 1945 superior procedures for carrying on this individual childstudy by groups of in-service teachers has been developed. Prescott explained the program thus:

It involves gathering an extensive body of information about each child and using this information to point to and validate the scientific facts and principles that explain the child's motivation, behavior, adjustment problems and current developmental tasks. Four major sources of information available to teachers are used: I) school records, including medical, dental and

'Daniel A. Prescott, "Communicating Knowledge of Children to Teachers," Child Development, XIX (March, 1948), p. 16 . 
health data, growth data, test data concerning intelligence, subject matter knowledge and basic skills, facts about the child's family, teachers' ovaluations of learning and conduct, and any anecdotal materials or samples of the child's earlier work; 2) home visits and conferences with one or both parents; 3) conferences with former and present teachers of the child and with other adults interested in him; 4) direct observations of the child in varied situations and objective, written descriptions of his behavior in anecdotal form during the period of the study. Each participating teacher also is a member of a child-study group of from eight to eighteen teachers which holds a two-hour meeting every other week during the school year. At each meeting one of the teachers presents the information she has gathered about a child, and the group as a whole interprets the behavior and needs of the child in terms of the explanatory scientific principles that seem indicated by the data about the child.

Continued for four or five years by the same group of teachers, this direct child-study method has proven itself much more effective than studying scientific generalizations in helping teachers to achieve a better understanding of their own pupils.

The needs of the teachers engaged in direct cinildstudy for more scientific facts and explanatory principles have been gradually met by occasional lectures by visiting consultants, by reading guided by annotated bibliographies, and by participation in two kinds of summer workshops. More than three hundred and fifty study groups involving about four thousand teachers have been served by the staff of the Field Program of Child Study. New and

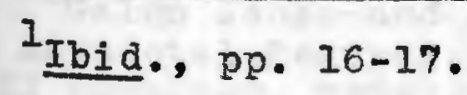


different procedures are constantly being suggested, tried, and evaluated.

These studies are only the beginning. More research is needed to determine the potentialities and weaknesses of the anecdotal record method.

Although the form to be followed in recording anecdotes has not been definitely agreed upon, the places for the date, the name of the observer, and the recording of the anecdotes have been generally accepted. One of the most complete forms, used as part of the Eight Year Experiment by Jones and Galbraith, provides space for name of the school, name of the subject, date, name of the observer, place of observation, and the objective anecdote. On the other side of the card is space for comment, generalizations, diagnosis, proposed remedial treatment, action taken or other statements the teacher may wish to record. ${ }^{I}$

This extensive review of the literature indicated that anecdotal records were not used as extensively as they might be in the public elementary schools. According to Bowes, none of the desirable purposes of the anecdotal record, namely, making teacher's analysis of a child's character more objective, suggesting next steps in helping

$I_{\text {Galen Jones and Adrin Galbraith, "An Fxperiment }}$ with Anecdotal Records, " Educational Research Bulletin, XXVIII (October, 1939), p. 189-202. 
the child, or adding satisfaction to the teacher's work in character development, has been served adequately by most teachers who use this guidance tool. ${ }^{1}$ Therefore, it is reasonable to assume that further research and derelopment in this area of pupil evaluation is needed. 


\section{CHAPTTER III}

\section{METHODS OF INVESTIGATION}

Several procedural steps were involved in planning, organizing, and executing the investigation involved in this study. In sequential order, a questionnaire was constructed, a letter was prepared, and planned visits were made to all elementary schools in the system during the second semester of the 1959-1960 school year.

Fach school visited and background data were referred to by number in order to protect the anonymity of each school. The background data were organized and presented by schools, subdivided into grades, number of boys, number of girls, and total number. In addition to the questionnaire on anecdotal records, was pertinent information with respect to the various schools, such as, name of school, grade, number of boys, and number of girls in the class. The questionnaire contained seven questions as well as identifying information for each school. The first group of questions pertained to the use of anecdotal records. The next group dealt with the reasons for their non-use. The last item concerned Itself with the teacher's personal idea of the value of anecdotal records. 
A letter was then prepared for each teacher in the Warwick elementary schools. The letter, Exhibit A, page 28 , invited the teachers to participate in this research project by answering the questions in the questionnaire, Fxhibit $B$, page 30 . In order to get the full understanding of the purposes of the anecdotal record, the writer felt it was necessary to state these purposes in detail. The letter also defined anecdotal records, stated the values of the anecdotal records, and explained the growing need for keeping such records. After constructing the letter, an appointment was made with the superintendent to explain the purposes of the letter and questionnaire. The writer went over the letter and questionnaire to explain the rationale of the study. The consent of the superintendent was obtained to visit and interview the principal of each school in the system.

A schedule was drawn up for vigiting principals in the system. In all but five instances, appointments were made by telephone. The remaining five appointments were made by visiting the schools personally. When making the appointment, the purpose of the visit was stated briefly. During the visit with the principal, copies of the selfexplenatory letter and questionnaire were given to her. An informal conversation followed, in which she was asked if there was any policy in her school with regard to the use of anecdotal records. Some principals had 
1 Hatherly Street

North Providence, R. I. April 1, 1960

Dear Fellow Teacher:

I am seeking your help in a research study I am making on the extent to which anecdotal records are being used in elementary schools, and on some of the possible reasons for their non-use. For the purpose of this study, an anecdotal record is defined as "a simple objective statement of an incident deemed by the observer to be significant with respect to a given pupil."

The use of the anecdotal record serves at least five important purposes. First, through continuous use throughout the elementary grades, it helps each teacher to have the benefit of previous teachers' experience in better understanding of each child. Second, it helps each teacher to become aware of the problems of individual children. Third, it provides objective data for guidance, especially for parent-teacher conferences. Fourth, it facilitates identification of the children who may need remedial work. Fifth, it enables the school administration to have a better basis for making improvements in the curriculum.

For many years there has been a question as to the extent to which anecdotal records can be used effectively in. aiding teachers to better understand their students. This is one of the areas in education in which much upto-date research is still needed.

You can help in the process of appraising anecdotal records by completing the enclosed brief questionnaire which should take only a few minutes of your time. Even if you do not use anecdotal records, your response to the questions will be much appreciated, since the opinions of all teachers are important. 


\section{EXIIBIT A - Continued}

A self-addressed, stamped envelope is enclosed for your convenience in returning the questionnaire. Your cooperation is Greatiy appreciated.

Sincerely yours,

Sylvia Antonelli

Enclosures 
EXIIBIT B

QUESTIONNAIRF ON THE ANECDOTAL RECORD

Name of School. Grade

Number of children in your class: Boys____ Girls___,

1. Do you use anecdotal records with your children? Yes_) No.

2. In general, how frequently do you use them?

3. For what children do you think anecdotal records should be required?

4. What positive benefits have you experienced from the use of anecdotal records?

5. What obstacles do you feel stand in the way of regular and sustained use of anecdotal records?

6. How do you think these obstacles might best be overcome? 
7. What do you frankly think about the practicality, ralue, and usefulness of anecdotal records in your school?

THANK YOU FOR YOUR COOPERATION

Sylvia Antonelli

I Hatherly Street

North Providence, R. I. 
questions concerning the definition, purposes, or uses of the record. Some principals gave some helpful information concerning their personal experiences with anecdotal records. The writer asked the principals to have the teachers indicate whether or not the anecdotal records were kept or included in case histories and conferences sheets only, or if they were actual objective notes taken and kept on a child's behavior. Miost of the principals were cooperative in answering questions concerning the use of anecdotal records in their schools. In order to get independent responses from each teacher, a self-addressed, stamped envelope was included with the letter and questionnaire. At the close of the interview, these were given to the principal and she was asked to give one to each of her teachers. In all but one instance, the questionnaires were returned directly to the writer. However, at School 15, the principal volunteered to collect the questionnaires and send them to the writer. The writer was able to visit twenty-nine of the thirty schools, including the one special school for retarded children (mongoloid, cerebral palsied, familial retardation, brain damaged) in which there are only ten in a class. Several efforts were made to arrange a visit with the principal of the school not included in the study, but obstacles beyond the control of the writer prevented this visitation from being made. 
Responses were received over a period of several weeks. From a total of 278 questionnaires distributed, 122 or forty-three per cent were returned. Responses were obtained from twenty-five of the twenty-nine schools visited. After receiving the responses, the results were tabulated in accordance with the questions. This facilitated putting the responses into categories for presentation and evaluation. In several instances when responses were not received, it was necessary to make a reminder visit. 


\section{PRESENTATION OF DATA}

Data were tabulated on all items included in the questionnaire. Table I presents identifying information of the twenty-five schools included in the survey. Table I summarizes the schools by number only, the grades represented, and the children represented. The grades represented in this study included the first six grades, four special classes, and three reading workshops. A grand total of 3469 children were represented in these groups, including 1842 boys and 1627 girls. The total number represented was tabulated as 134 rather than 122 since twelve responses included two grades and were tabulated under both grades.

The first item on the questionnaire asked, "Do you use anecdotal records? yes or no." of the 122 responses, fifty-nine teacherg indicated that they used anecdotal records and sixty-three indicated that they did not use them.

Another valuable source of information regarding the use of anecdotal records came from personal interviews with twenty Warwick elementary principals. (Six are principals of more than one school.) The reactions 
of the principals to the use of anecdotal records fell into three catagories, almost complete agreoment, agreement with reservations, and almost complete disagreement. Most of the principals agreed with reservations that anecdotal records should be used.

Three of the twenty principals were in almost complete agreement with the use of anecdotal records. One of the prinoipals expressed it in the following manner: "Because this is the only special school for retarded children in Warwick, classes are limited to ten, and formal anecdotal records are kept for each child. They are necessary for the Mental Hygiene Clinic and the Child Guidance Clinic." Another principal said, "They are very helpful when conferring with doctors, school psychologists and psychiatrists, and clinics."

Fourteen principals agreed with reservations. Typical reactions were as follows: "The teachers do not use or keep anecdotal records. I write, use, and keep them for particular cases." "Although I do not believe in the use of formal anecdotal records, I recommend that teachers keep a few notes on problem children and attach these notes to the case histories." "Anecdotal records may be helpful if the teacher used them only in a few cases."

Only three principals expressed almost complete disagreement with the use of anecdotal records. Their 
selfiments were as follows: "Because the records become a part of the child's cumulative record, future teachers may be prejudiced against a child, unfounded biases may become present, thus creating an unfair situation." "Because of the time element, I doubt that many individual teachers keep anecdotal records."

There is evidence from principals' responses that they consider some teachers to be incompetent. For example, one prineipal who seemed to have a thorough understanding of anecdotal records stated that she had adrised only about ten teachers to use them since 1955, because although she had used them for many years, she felt that anecdotal reoords had proven helpful in only a few cases. She also felt that teachers need more training in the total process of using anecdotal records. It was apparent from interviews with eight of the principals that these individuals seemed to have some misconceptions concerning the true and proper meaning of anecdotal records. From their responses in the interview, it was evident that they thought anecdotal records were statements put on conference sheets and case histories as well as information on permanent record cards instead of "a simple objective statement of an incident deemed by the observer to be significant with 
respect to a given pupil."l

TABLE 1

SCHOOIS, GRATES, AND CHIIDREN REPRESEITIED

IN THE QUESTIONAAIRE RESPONSES

\begin{tabular}{|c|c|c|c|c|c|c|c|c|c|c|c|}
\hline \multirow[t]{2}{*}{ School } & \multicolumn{8}{|c|}{ Grades Represented } & \multicolumn{3}{|c|}{ Children Represented } \\
\hline & 1 & 2 & 3 & 4 & 5 & 6 & $\mid \begin{array}{l}\text { Spe- } \\
\text { cial }\end{array}$ & $\begin{array}{l}\text { Read- } \\
\text { Ing } \\
\text { work- } \\
\text { shop }\end{array}$ & Boys & Girls & Total \\
\hline $\begin{array}{r}1 \\
2 \\
3 \\
4 \\
5 \\
6 \\
7 \\
8 \\
9 \\
10 \\
11 \\
12 \\
13 \\
14 \\
15 \\
16 \\
17 \\
18 \\
19 \\
20 \\
21 \\
22 \\
23 \\
24 \\
25\end{array}$ & $\begin{array}{l}2 \\
2 \\
1 \\
1 \\
3 \\
1 \\
1\end{array}$ & $\begin{array}{l}1 \\
1 \\
1 \\
2 \\
1 \\
1 \\
2 \\
1 \\
3\end{array}$ & $\begin{array}{l}1 \\
1 \\
1 \\
1 \\
3 \\
1 \\
3\end{array}$ & $\begin{array}{l}2 \\
2 \\
\\
1 \\
1 \\
3 \\
1 \\
2\end{array}$ & $\begin{array}{l}2 \\
1 \\
1 \\
2\end{array}$ & $\begin{array}{l}2 \\
1 \\
2 \\
1 \\
2 \\
1 \\
2 \\
1 \\
3\end{array}$ & $\begin{array}{l}2 \\
1\end{array}$ & $\begin{array}{l}1 \\
1\end{array}$ & $\begin{array}{r}32 \\
47 \\
5 \\
63 \\
8 \\
101 \\
23 \\
38 \\
43 \\
104 \\
58 \\
17 \\
153 \\
89 \\
252 \\
24 \\
11 \\
145 \\
135 \\
35 \\
16 \\
77 \\
190 \\
32 \\
144\end{array}$ & $\begin{array}{r}33 \\
48 \\
11 \\
56 \\
17 \\
99 \\
33 \\
27 \\
38 \\
92 \\
65 \\
14 \\
134 \\
69 \\
217 \\
7 \\
2 \\
136 \\
117 \\
22 \\
6 \\
72 \\
156 \\
23 \\
132\end{array}$ & $\begin{array}{r}65 \\
95 \\
16 \\
119 \\
25 \\
190 \\
56 \\
65 \\
81 \\
196 \\
123 \\
31 \\
287 \\
158 \\
469 \\
31 \\
13 \\
281 \\
252 \\
57 \\
32 \\
149 \\
347 \\
55 \\
276\end{array}$ \\
\hline Total & 22 & 23 & 19 & 22 & 20 & 21 & 4 & 3 & 1842 & 1627 & $\overline{3469}$ \\
\hline
\end{tabular}

I Zahn, op. cit. "The Anecdotal Record in Relation to Child Development," Education for Dynamic Citizenship, p. 294. 


\section{TABIE 2}

ANAIYSIS OF FREQUENCY OF USE OF ANECDOTAL RECORDS BY FITIY-NINE TEACHERS USING THEHF

Frequency of Use

1. Conferences with parents - twice a year 30

2. When occasion arises 23

3. Often -- dally; weekly; once or twice a week; several times a year; every three weoks; early in the year

4. Occasionally -- twice a month; once a month; five or six times a year; three or four times a year

5. Beginning of the year

6. Request of principal

Total

$\overline{98}$

The second question asked, "How frequently do you use anecdotal records?" A wide variety of responses were made to this question by the fifty-nine teachers using anecdotal records. It is to be noted on Table 2 that the total of frequency of mention is more than fifty-nine, totaling ninety-eight. This means that on several questions teachers indicated more than one basis for use. A major basis for use of anecdotal records appeared to be conferences with parents. 
However, this would not preclude teachers using anecdotal records when the occasion arises as cited by twenty-three teachers. Nineteen indicated in general that they use the records often. Fighteen indicated occasional use of the records. Six teachers used them often in the beginning of the year; and two on the request of the principal. In general, the majority of the fifty-nine teachers indicated using anecdotal records on a reasonably frequent basis.

\section{TABIR 3}

FREQUENCY OF MENTION BY EIEMANTARY TEACHERS OT CONDITIONS WHICH PROMPTED THE USE OF ANECDOTAL RECORIS

1. Problem cases -- behavior; discipline; social; adjustment; emotional, difficulties

2. AII

3. Emotionaliy disturbed

4. Underachievers

5. Academic failures

6. Gifted children -. exceptionally fast; superior

7. Physically handicapped

8. Retarded

9. Poor health Total 
think anecdotal records should be required?", there were 179 responses. In this group only thirty-six of the 179 responded "all". Forty-eight responded that records were kept for children who showed discrepencies in school achievement such as: exceptional (fast or slow), below grade level, repeaters, difficulties and non-abilities, gifted, low ability, deviate from normal, scholastically maladjusted, and underachievers.

Among the other responses, substantial numbers were shown to keep records for discipline problems. The remaining eighty-seven kept records for a variety of reasons which included: problem cases, emotionally disturbed, child with a problem, child with a social problem, adjustment difficulty (maladjusted), socially maladjusted. Since sixty-nine of the 179 were kept for problem cases, there seemed to be a considerable concern for keeping records for "problem children." As indicated above, the problem was expressed in different terminology, depending upon the way the teacher generalized about her experiences with chlldren who have problems. In addition to the above, some teachers stated that they kept records for children exhibiting unpredictable or irrational behavior.

The physically handicapped was another group for whom teachers kept records. In proportion to the other categories for whom records were kept, this classification was low since only six teachers kept records for the 
physically handicapped. Those who kept records for this group stated that they felt it was important since physical well-being or lack of it can be a major reason or cause for a child's undesirable behavior. Two teachers kept reoords for those in poor health.

It is evident from Table 3 that anecdotal records are kept for widely different reasons. There appears to be a tendency for records to be written in large part for behavior that deviates negatively from the normal. It is interesting to note that only a few kept records for the academically accelerated.

\section{TABIE 4}

POSITIVE BENETITS FIXPERTENCED BY EIEMENTARY TEACHERS FROM THE USE OF ANECDOTAL RECORDS

1. Understanding

32

2. Accuracy

21

3. Previous teacher's experience

20

4. Diagnosis

11

5. Prevention

6. Special cases or deviation Total

91

In response to item 4, "What positive benefits have 
you experienced from the use of anecdotal records?", ninety-one of the 122 or serenty-four per cent of the teachers experienced positive benefits from the use of anecdotal records. Thirty-two teachers mentioned understanding children as being the greatest benefit derived from the use of anecdotal records. It was stated in such terms as, "understanding emotional problems," "understanding capable children not working up to grade level," "better understanding of the home and parental background," "understanding children's problems and giving aid in solving these problems," "a means to helpIng the child," "gave greater insights into particular child's problem."

Twenty-one teachers placed great value on anecdotal records as a help in keeping the records more accurate. This was stated in various ways such as, "reference for conferences," "referral to guidance department," "refresh memory at report and conference time," "used to explain child's behavior to parent," "helps recall given statement or situation concerning individual," "specific facts on hand."

Twenty teachers stated that they found benefits from previous teacher's experience. This was stated in such terms as, "helps in planning for child early in the year," "help in handling of child by noting previous teacher's records," "comparing own impressions with other teachers," "notice improvement and changes," "methods 
found successful by previous teachers," "see child's previous behavior and academic weakness."

Aid in diagnosing was mentioned by eleven teachers as being a positive benefit. This was expressed in such ways as, "aid in coping with situations peculiar to given students," "behavior patterns," "helpful in alagnosing individual needs," "confirm or disprove your jdeas about a child," "clear areas of doubt and problems," "help eraluate the pupil."

The anecdotal record was cited by four teachers as contributing to prevention of undesirable behaviox. This was stated as, "avoid emotional upsets by being forewarned of child's temperament and needs," "pin point specific classroom situations which will bring an undesirable response from the pupil," "correct re-occurrence of a particular problem."

Three teachers stated that the use of anecdotal records provided insight into special cases or deviations in behavior. This was characterized by the following quotes, "trace social, emotional, academic growth of disturbed child and relate it to day by day experiences," "handling behavior problems, health problems, and in approach to teaching slow children." 


\section{TABIE 5}

OBSTACINS ACCOUNTING FOR THE IRREGUIAR AND UNSUSTAINED USE OF ANECDOTAI RECORDS BY ELETHENTARY TFACHERS

1. Time consuming.

2. Iimited knowledge in psychology difficult to write objectively; misinterpretation of implication; obstacle in regard to evaluation.

3. Prejudice against child -- aversion to writing detrimental things.

4. Communication -- not always a true picture.

5. Administrative problems -- repetition of statement; hard to catalogue; no standard forms; accumulation of material.

Total

The fifth item was the question, "What obstacles do you feel stand in the way of regular and sustained use of anecdotal records?". Of the 148 responses to this item, there were 136 statements about obstacles. Only twelve teachers of the 122 replying stated that they felt there were no obstacles. Sixty-eight teachers found the keeping of aneodotal records too time consuming. It was stated in such terms as, "can be time consuming," "these 
records are time consuming and take away from the learnIng situations of the individuals concerned and the rest of the class," "requires too much time in addition to other records which are kept for each child," "time element -- teachers do not have the time required for sustained use," "lack of time."

Twenty-nine teachers stated limited knowledge in psychology as being the reason for irregular and unsustained use of anecdotal records. Among the terms used were, "insufficient knowledge in psychology for average person to understand records," "teachers do not understand their use or what makes a good anecdotal reoord," "teachers need more training in them," "can be misconstrued by inexperienced teacher." Prejudice against the child was the reason given by twenty-three teachers. They used the following terms to explain this: "Difficult to write objectively," "some teachers do not like to have detrimental things written," "prejudice against the child." Less frequentiy mentioned were communication and administrative problems. Nine teachers mentioned the former and seven the latter. Nine teachers used the following terms: "Teachers may become too faultinding, thus creating unnecessary problems," "principals injecting wording into records in contradiction to teachers," "lack of honesty and complete reporting by some," "too much emphasis on 'bad' actions," "may be used as the only 
means of obtaining information." Seven teachers explained administrative problems in the following way: "Hard to catalogue," "no standard forms," "accumulation of material."

\section{TABIE 6}

ETHPMENTARY TEACHERS' SUGGESTIONS FOR

OVHRCOMING OBSTACIPS TO THE USE

OF ANECDOTAL RECORDS

Responsibility for

Overcoming Obstacles
Frequency

of Mention

1. Administration

2. Teachers

27

3. More study

Out of eighty-six responses to item 6 , "How do you think these obstacles might best be overcome?", there were seventy-eight statements about overcoming obstacles. Four stated that the obstacles cannot be overcome; and four stated that they did not know. Thirty-five mentioned that the administration might help in some way. Among suggestions for improvement in administration were, "allotting more school time for preparation of the records," "have printed forms available," "clerical duties undertaken by an extra person," "smaller classes," "more guidance consultants to help teachers in making and keoping 
records."

The twenty-seven teachers who felt that the teachers themselves could help overcome these problems stated it in the following terms: "Iimited use -- such as keeping records for unusual social or behavior problems, reinforcement of teacher's thinking, or origin of the problem," "teachers should form their own opinions before reading previous records," "discard records which no longer apply to the case," "consideration of ains and uses for these records should dictate the number and type required." Some teachers felt that teachers should feel free to say what they think and not have to "gloss over" in conferences.

The last sixteen felt that more study and establishment of the value of sustained anecdotal records would help overcome the obstacles. This was stated thus: "Inservice training workshop courses," "more courses in child development, guidance, and psychiatry," "more literature on the subject," "careful study and correct use of the records," "better knowledge on the part of all of the value of such records," "make records voluntary and point out benefits." As indicated above, the teachers had many suggestions for overcoming these obstacles of which they are aware. 
ESTIMATE OT PRACTICALITY, VALUE, AND USBFULINESS OF ANECDOTAI RECORDS BY 106 ELEMAENTARY TEACHERS

Practicality, Value, Usefulness

Number Responding
Percentage of Total
1. Very positive

2. Slightly positive

3. Indifferent

4. Slightly negative

5. Very negative

Total
25

59

6

12

11

$\frac{4}{106} \quad \frac{3}{100}$

Item 7 asked the question, "What do you frankly think about the practicality, value, and usefulness of anecdotal records?". It appears from Table 7 that most of the 106 teachers answering this question have a positive reaction to the use of anecdotal records. More teachers have a slightly positive reaction than a very positive reaction, since there are fifty-nine of the former and twenty-five of the latter. Very positive reactions were characterized by such statements as, "very valuable," "Indispenaeble," "very helpful in working with children who have been chronic problems in school," "very good for guidance department." Slightly positive 
reactions were stated as, "useful," "helpful if child is benefited, not condermed by them," "good," "valuable in any school, but the teacher can do just so much." Six teachers were indifferent. This attitude was characterized by such statements as, "don't know," "only when necessary," "not too much for time and energy needed for it," "useful and annoying." Twelve teachers were slightIy negative in their statements, characterized by the following remarks: "Practical for teacher's own use, but take too much time if they have to be checked," "not too many values except for case histories and guidance reports," "not too helpful," "question value of records for all students -- too repetitious." Only four teachers stated very negative reactions to this item. These were stated thus: "Too much paper work," "too time consuming," "we have reached a saturation point," "time spent is highly out of line with what is returned from them."

The 106 teachers who responded to the final question were generally more oriented toward positive than negative values. It is to be observed from Table 7 that eightyfour responses were on the positive side or seventy-eight per cent of the total. On the other hand, only sixteen responses were negative or fifteen per cent of those teachers who responded. 


\section{CHAPTER V}

\section{SUMAARY AND RECOMDERDATIONS}

\section{Summary}

The two-fold purpose of this investigation was to find out the extent to which anecdotal records were being used in the Warwick elementary schools, and to determine the possible reasons for their non-use by various teachers. In an attempt to get data on this problem, approaches were made in two major categories of investigation. One phase of the investigation was a personal interview with twenty principals, representing twenty-nine schools in the Warwick system. The second phase of the study involved obtaining responses to a questionnaire filled out by the teachers of these schools. The questionnalre was given to the teachers by the principals. Responses from the interviews and questionnaires were recorded, tabulated, and evaluated with regard to the central problem of this thesis.

A fow principals were strongly in favor of the use of anecdotal records and a few principals expressed a negative reaction. However, most of the principals followed the middle-of-the-road path, appearing mildly enthusiastic. In forty per cent of the interviews it 
seemed evident that the principals had some misconceptions concerning the true meaning of anecdotal records. They appeared to perceive anecdotal records as including statements on case conference and case history sheets as well as notations on permanent record cards rather than direct observations, with interpretation, of significant behavior. This would lead one to question whether a principal who did not understand anecdotal records fully could lead her teachers in understanding them or exert leadership in carrying out an anecdotal record program.

In spite of efforts to obtain a higher percentage of responses, a disappointingly low forty-three per cent of the teachers responded. It was not possible to draw conclusions from those not responding. The low percentage of responses may have been due to the disinterest of the principals or the fact that the problem of anecdotal records is not of vital concern to a majority of the elementary teachers in the system. There appeared to be a difference of opinion concerning the use of anecdotal records. The fact that fifty-nine teachers indicated that they used anecdotal records as opposed to sixty-three who did not use them seemed to confirm the hypothesis that anecdotal records were not being used as extensively as they might have been used in the Warwiok elementary schools. The fact that there are only four more teachers who did not use anecdotal records than did use them seemed to indicate that the teachers, like the principals, 
might have thought that they were keeping anecdotal records on conference sheets and reports on case histories which were too general to be considered anecdotal records. If this were not the case, perhaps more teachers would have indicated that they did not keep anecdotal records. Concerning the use of anecdotal records, it was found that most frequently, anecdotal records were used for conferences with parents and for problem cases. Parent conferences were held in all schools twice a year. At this time the teacher and parent net to discuss a child's scholastic progress and social growth. These conferences were an important part of the school program in which parents asked many questions which the teacher felt she must answer and have specific bases for these answers. Often irate parents wanted to know specifically the teacher's reasons for saying that the child exhibited negative behavior characteristics. For this purpose, teachers found that anecdotal records have proven valuable in coping with this situation of urgenoy. Since conferences are required in all schools, this would seem to indicate that teachers find aneodotal records helpful for this compulsory phase of the school program.

In addition to keeping records for parent conferences, many teachers kept them for problem cases. Teachers seemed to feel that there must be reasons for children deviating from the normal behavior pattern, reasons for their problems, and for their creating 
problems; therefore, the teacher felt that it was imperative that she get to the core of the problem. The fact that most teachers kept records for behavior cases seemed to indicate that there is a great deal of concern for chilaren who present problems of any kind to the teacher. Also, the largest number of those responding answered this question, "For what children do you think anecdotal records should be required?"

The questionnaire revealed that anecdotal records were seldom kept for children in poor health in spite of the fact that all teachers have been cautioned to be on the look out for ill health symptoms. Although poor health is referred to the school doctor or nurse, the fact that only a few kept records for those in poor health lead to the conclusion that teachers were not as concerned with the child in poor health as with the child presenting a problem or the child who deviated from the normal. This was surprising, since physical well-being or lack of it can be a major reason for a child's undesirable behavior. It does not seem that teachers are getting to the core of the problem. It may also indicate that many teachers are more interested in their subject matter than they are in the individual child, and they believe that their subject matter can best be presented to a class in which there are a few if any problem cases or deviates.

Many teachers' responses to items in the questionnaire were brief. A large number of these brief responses 
seemed to reflect indifference. However, from those questionnaires that were returned, it appeared that the teachers were more positive than the principals in their responses to anecdotal records. In contrast to the prinoipals, they had very definite ideas for or against the use of anecdotal records.

Seventy-four per cent of the teachers stated that they experienced positive benefits from the use of anecdotal records. The most frequently mentioned benefit was that of better understanding of the pupil, an indication of moving in the direction of greater effort to understand and appreclate the dynamies of individual behavior.

In addition to better understanding, accuracy ranked second in the list of positive benefits experienced from the use of anecdotal records. The concern for accuracy would seem to indicate that teachers prefer specific rather than general statements.

Teachers seemed to feel that previous teacher's experiences with a child had proven beneficial in their own dealings with the youngster. Of course, this positive benefit should be used in an effort to help the child and not to prejudice the teacher. This would seem to indicate that teachers valued the findings of other teachers and considered guidance (anecdotal records), like education, an ongoing process.

The teachers responding to the questionnaire indicated a number of factors standing in the way of more 
effective use of anecdotal records. Until these obstacles have been overcome, it is likely that the anecdotal record will follow the same pattern of non-use in the Warwick elementary schools that has been the case since the early 1930 's. Time consumption was stated as being the greatest obstacle, a fact which was not surprising since many teachers feel over-worked and they are not sensitized to the values which might be gained from using anecdotal records.

Limited knowledge in psychology on the part of the teacher was found to be another obstacle. Too few teachers have taken advantage of the psychology courses offered by colleges and universities. Perhaps they felt it was an abstract discipline in which they preferred not to delve. From the results of this study, it was reasonable to conclude that the lack of psychological background of many teachers offered them at least an excuse for not using anecdotal records.

The teachers offered several suggestions for overcoming these obstacles. They stressed the role of the administration in helping to overcome the obstacles in terms of allccation of more school time for the preparation of records, provision of forms for anecdotal recording, some clerical help for relieving teachers of clerical details, and consulting assistance in making and keeping records. In general, they looked upon the administration for support and encouragement. 
Other suggestions for overcoming obstacles to the use of anecdotal records were in the direction of more initiative and resourcefulness of the teachers themselves. The tone of these responses seemed to indicate that teachers need to take a more professional view of the ways by which these records could be used. They suggested strongly that a program of in-service training on anecdotal records would help teachers to gain greater professional insight.

Another method of finding the teachers' honest opinions concerning the practicality, value, and usefulness of anecdotal records was to categorize their responses. Most of the teachers made slightly positive statements concerning the practicality, value, and usefulness of anecdotal records. Very positive statements ranked second. Slightly negative statements ranked third, followed by statements of indifference and very negative statements. On the whole, it appeared that most teachers felt that anecdotal records were practical, valuable, and useful. Comparatively few teachers felt that they were not practical, valuable, and useful. There were some that were indifferent, a fact probably accounting for the lack of responses in the questionnaire. Since only a few had very negative feelings, it indicated that there was hope for anecdotal records because many teachers would use them if the obstacles were overcome and the teachers 
felt more qualified.

\section{Recommendations}

Based upon the general findings as well as the experience of the writer in teaching, discussing, and observing, the following are recommendations which seemed reasonable within the Warwick school system:

Anecdotal records should be voluntary if they are to be of any value. The teacher must see the value in them and want them and not feel compelled to write a certain number to hand in at the end of the week. If they are compulsory, it may be difficult to get quality statements. Careless statements without basis or statements written in haste may be made to fulfill the requirement of a certain number of anecdotes for each child. The teacher may then develop an "eagle eye" watching every move of the child in anticipation of an act that can be put into the record. This would not characterize an atmosphere conducive to optimum learning and personality growth.

In-service training courses for teachers as well as workshops would result in valuable and more complete records. Many obstacles to be overcome may be taken care of in these in-service training courses. These courses and workshops would be open to all interested teachers for the specific purposes of making teachers aware of the values of anecdotal records, acquainting teachers 
with the purposes and uses of anecdotal records, and to clear up any misconceptions that teachers might have. This would be an ongoing program given each year and recurring as new developments came into focus.

Case conference techniques in which the teacher and guidance consultant discuss a youngster should be established. For this, the anecdotal record becomes an important part of the conference. This would help the teacher to understand the child. As a result of this successful developmental programs, in which the teacher showed the youngster his path of development, could exist.

Anecdotal records should be applied and used to help the chlld. The writing alone, if they are put in the teacher's drawer or in the child's folder and kept there in anticipation of future use, will not necessarily help the child. It is writing the anecdotes, plus the application and use that constitute a successful anecdotal record system.

In order that labor be less of a burden to the elementary teacher, extra clerical help should be made available to assist the teacher. Ideally, the number of persons required would depend on the number of grades and classes in a school as well as on the quality of the person hired. One mature, competent clerk is all that might be required for just processing anecdotal records. 
Great care should be taken to hire a person of maturity and personal integrity so that none of the material in anecdotal records would go beyond the school.

Since education and guidance are developmental processes, anecdotal records, as one guidance tool, becomes a technique in a developmental process. Therefore, they should be kept for all children and considered an important part of the child's cumulative record. Many youngsters will experience little or no difficulty, appear to be no problem, or have no problem in the early grades, but in junior high may develop difficulties or problems. It then becomes helpful to have anecdotal records available from the child's early years in school. This is an essential aid in tracing the child's development from oarly school years.

To allay the effects of any prejudices the teachers might have, the writing of the year-end summaries should become the responsibility of the guidance consultant. This should be done after conferring with the teacher. At the outset of this study, the writer was somewhat skeptical about the value of anecdotal records. As a result of the experiences involved in this investigation, the thinking of the writer has been modified considerably in the direction of more positive values and possibilities of anecdotal records. This remains an area in education, especially at the elementary 
Ievel, where much improvement is needed if this important guidance tool is to contribute more positively to the development of children. 


\section{BIBLIOGRAPHY}

\section{Books}

Hamalainen, Arthur F. An Appraisal of Anecdotal Records. Teachers College Contribution to Education No. 891 ; Tew York: Bureau of Publications, Teachers College, Columbia University, 1943.

Jarvie, I. I., and Fllingson, Mark. A Handbook on the Anocdotal Behavior Journal. Chicago: University of Chicago Press, 1940.

Magnuson, Henry W., Larson, Carl A., and Shellhammer, Thomas A. Evaluating Pupil Progress. Bulletin of the California State Department of Education, Vol. XXXI, No. 6; Sacramento, California:

California State Department of Education, April, 1952.

Raths, Louis. Anecdotal Records. Bulletin No. I; Progressive Fducation Association, Evaluation in the Fight-Year Study; Columbus, Ohio: Ohio State University, September, 1935.

Research Evaluating A Child Study Program. Growth and Development Konographs, XXI, Child Development Publications, Purdue University, Lafayette, Indiana, 1956.

Smith, Eugene R., Tyler, Ralph W., and the Evaluation Staff. Appraising and Recording Student Progress, Chapter $\bar{X}$. Report of the Fight-Year Study of the Progressive Fducation Association; New York: MoGraw-Hill Book Co., Inc., 1942.

Thomas, Dorothy Swaine, and Associates. New Technigues for Studying Social Behavior, Child Development Monographs No. I; New York: Bureau of Publications, Teachers College, Columbia University, 1939.

Torgerson, Theodore I. Studying Children. New York: The Dryden Press, 1947. 
Traxler, A. E. Techniques of Guidance. New York: Harper and Brothers, 1945.

Traxler, A. E. The Nature and Use of Anecdotal Records. New York: Educational Records Bureau, 1939.

Zahn, Willard D. Education for Dynamic Citizenship, "The Anecdotal Record in Relation to Child Development," Twenty-fourth Annual Schoolmen's Week Proceedings; Philadelphia: University of Pennsy Ivania, School of Education, January 25, 1937, pp. 294-300.

\section{Periodicals}

Arrington, Ruth $\mathrm{E}$. "Time Sampling in Studies of Social Behavior: A Critical Review of Techniques and Results with Research Suggestions," Psychological Bulletin, XI, February, 1943, pp. 81-124.

Barr, A. S. "On the Use of Anecdotal Records," Journal of Educational Research, XXXIV, January, I94I, pp. 358-360.

Bicker, H. "Using Anecdotal Records to Know the Child," Fostering Mental Health in Our Schools, pp. 184-202. Association for supervision and Curriculum Development, 1950 Yearbook. Washington.

Blatz, William $\mathrm{E}$. , and Blott, E. A. "Studies in Mental Hygiene of Children. Behavior of Public School Children: A Description of Method," Pedagogical Seminar and Journal of Genetic PsycholoEV, XXXIV, December, 1927, pp. 552-582.

Bowes, Fern H. "The Anecdotal Behavior Record in Measuring Progress in Character," Flementary School Journal, XXXIX, February, 1939, pp. 431-435.

Bright, Harold, and Hunsucker, Florise. "Use of the Anecdotal Behavior Journal in Student Training," Teachers College Journal, Indiana State Teachers College, IX, September 16, 1937, pp. 6-7.

Charters, W. W. "A Character Development Study," Personnel Journal, XII, August, 1933, pp. 119-123.

Darsie, M. I. "Evaluating the Intangibles," California Journal of Secondary Education, XII, March, 1939, pp. $275-27 \%$. 
Goodenough, Florence $I$. Measuring Traits by Means of Repeated Short Samples," Journal of Jurenile Research, XI, 1928, pp. 230-235.

Harris, D. B. "Use of the Anecdotal Behavior Journal in a Correctional School for Boys," Journal of Juvenile Research, XXII, July, 1938, pp. 162-168.

Jarvie, I. I. "Quantitative Study of Behavior Records," American Educational Research Associ= ation: Official Report, 1939.

Jarvie, I. I. "Some Factors Bearing on the Use of Anecdotal Records," American Educational Research Association: Official Report, 1940.

Jersild, Arthur T., and Meigs, Margaret F. "Direct Observation as a Research Method," Review of Educational Research, Ix, December, 1939, pp. 472-482, 597-599.

Jones, Galen, and Galbraith, Adrin. "An Experiment with Anecdotal Records," Educational Research Bulletin, XXVIII, October, 1939, pp. 189-202.

Jones, Harold E. "Observational Methods in the Study of Individual Development," Journal of Consulting Psychology, IV, December, 1940, pp. 234-238.

McCormick, C. F. "Some Factors Bearing on the use of Anecdotal Records," School and Socjety, IIII, January 25, 1941, pp. 126-127.

Prescott, Daniel A. "Commicating Knowledge of Children to Teachers," Child Development, XIX, March, 1948, pp. 15-24.

Randall, J. A. "The Anecdotal Behavior Journal," Progressive Education, XIII, January, 1936, pp. $21-26$.

Smith, Morpheas. "Concerning the Magnitude of the Behavior Sample for the Study of Behavior Traits in Children," Journal of Applied Psychology, XV, October, 1931, pp. 408-485.

Tyler, Ralph W. "Techniques of Evaluating Behavior," Educational Research Bulletin, XIII, January, 1934, pp. 1-11. 
Whittenburg, Clarice. "Plea for the Anecdotal Record," School Executive, IXIV, June, 1945, pp. 44-46.

Wilson, C. O. "Evaluation of Child Growth: An Anecdotal Record," Educational Method, XX, January, 1940, pp. $178-181$.

Wood, Ben D. "Information for Guidance--The Anecdotal Record," Occupations, XIII, June, 1935, pp. 795803 .

Wood, Ben D. "The Hajor Strategy of Gui dance," Educational Record, XV, October, 1934, pp. 419444. 